\title{
Underground Support System Determination: A Literature Review
}

\author{
Rio Aditomo Mahardika Putra* \\ *rio.aditomo.ra@gmail.com
}

Faculty of Engineering, Civil Engineering Department, Lampung University, Jl. S. Brojonegoro No. 1, Bandar Lampung, Indonesia

\begin{abstract}
Research on underground structure has been carried out by many researchers from around the world in order to create an underground space that can be utilized for various human purposes. One thing that must be considered in the underground structure is the support system which has objective to control the deformation of rock mass caused by stress distribution during or after the underground construction process. This literature review describes the distinction of supporting elements according to their characteristics and functions in a support system. The selection of supporting elements by empirical approach and finite element method will also be discussed in this paper. Grout injection and grout bolt are support elements that function as reinforcement. Friction bolt and mechanical point anchor serve to hold whilst mesh, straps, steel set, shotcrete and concrete lining serve to retain loose rock from falling. Both empirical approach and finite element method have its own strengths and weaknesses in determining the support system and therefore must be used together to produce a safe design according to the geological conditions of the project site. This article tries to help the contractors, engineers and designer in selecting appropriate support system in order to ensure safety of its users.
\end{abstract}

Keywords: Underground structure; Support system; Rock mass classification; Finite element analysis

\section{Introduction}

The rise of the world's population has led to an increasing need for space to build more public facilities. In densely populated urban areas, the construction of public facilities has its own challenges. Utilization of underground space can help cities deal with this problem. Research on underground structure has been carried out by many researchers from around the world in order to create an underground space that can be utilized for various human purposes. Public facilities such as subway, utility tunnels, aqueducts and underground basements are some examples of the application of the use of underground space. One thing that must be considered in the underground structure is the support system. The objective of the support system is to control the deformation of rock mass caused by stress distribution during or after the underground construction process (Gharouni-Nik, 2013).

Rock mass is formation of blocks of material separated by various types of geological discontinuities. A discontinuity is here defined as any significant mechanical break or fracture of negligible tensile strength in a rock (Priest, 1993). The types of discontinuities are defined as faults, joints, bedding, fractures, cracks, and fissures. Instability of rock discontinuities can be the cause of ground deformation. Five of the most important 
factors of instability in jointed rock masses are due to unfavorable geological features, excessively high stress, incorrect sequences of mining, poor physical properties of rocks, and excessive ground water pressure (Chen, 1994).

There have been a number of collapses tunnels worldwide due to the failure of support system. One of the worst civil engineering disasters in the United Kingdom happened during the night of $20^{\text {th }}$ October 1994. During this night several tunnels undergoing construction beneath Heathrow Airport's Central Terminal Area (CTA) collapsed completely. Luckily no one was injured in this incident but some neighboring building and structures got severe damage (Schutz, 2010). It was concluded that the direct cause of the incident was a series of events such as poor design and planning, lack of quality during construction, lack of engineering control, and lack of safety management. Other tunnel collapse event occurred in expressway tunnel (shallow tunnel) through Chaoyang mountain of Qingdao China which collapsed during construction on $26^{\text {th }}$ September 2015. Analysis showed that the main cause of shallow tunnel collapse is lack of right side-wall-support which leads to the upper right surrounding rock unstable ( $\mathrm{Li}$ et al., 2020). The two examples of tunnel collapse incidents show that the support system has an important role in the subsurface structure. Both practitioners and researchers from around the world have tried to make various formulas for the support system that can be used in an effort to achieve stability of underground structures.

Various kinds and types of supporting elements have been introduced by manufacturers which of course must be accompanied by a deep understanding of the characteristics and functions. This literature review describes the distinction of supporting elements according to their characteristics and functions in a support system. The selection of supporting elements by empirical and finite element method will also be discussed in this paper. This article tries to help the contractors, engineers and designer in selecting appropriate support system in order to ensure safety of its users.

\section{Principles of Support System}

The primary objective of a support system is to mobilize and conserve the inherent strength of the rock mass so that it becomes self-supporting (Hoek \& Wood, 1987). The mechanism of the underground support system is very complex and there is no model that can fully explain the relationship between various supporting elements in a support system. Hoek \& Wood (1987) defines two characteristics of support system, namely active support and passive support. Active support is act as a rock mass reinforcement. As the name implies, it is used to increase strength in preventing the deformation behavior of the rock mass and is the same as the function of steel reinforcement used to strengthen concrete. Passive support is used to prevent loose rock from separating which the reinforcement function cannot do.

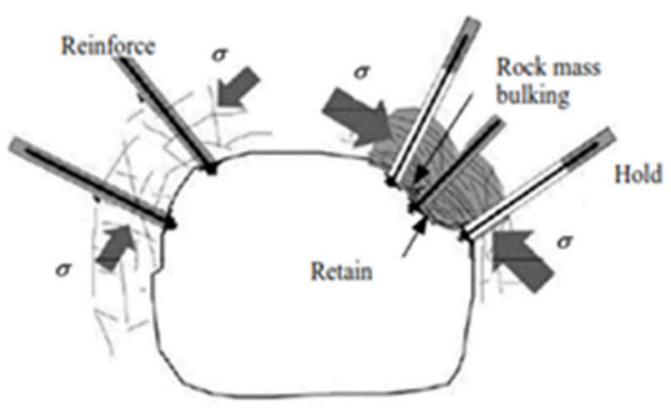

Figure 1 The three main functions (reinforce, retain, hold) of support system (Kaiser et al., 1996) 
Other researcher, namely Kaiser et al. (1996) also tried to formulate three distinctions of support system function which illustrated in Figure 1., namely:

- To reinforce rock mass,

- To retain loose rock from falling, and

- To hold a less stable rock layer to a more stable rock layer

The installed support system must be able to absorb all dynamic energy in the rock mass arising from activities in the underground either during the construction period or during the service period. The three main functions of the support elements must form an integrated support system for the stability of the underground structure.

\section{Type of Support Elements}

\subsection{Rock bolt}

Rock bolt is the most widely used support element in a support system in any underground structure. The rock bolt application design consists of selecting the type, determining the length and the installation spacing (Li, 2017). There are several types of rock bolt, namely friction bolt, grout bolt and mechanical point anchor.

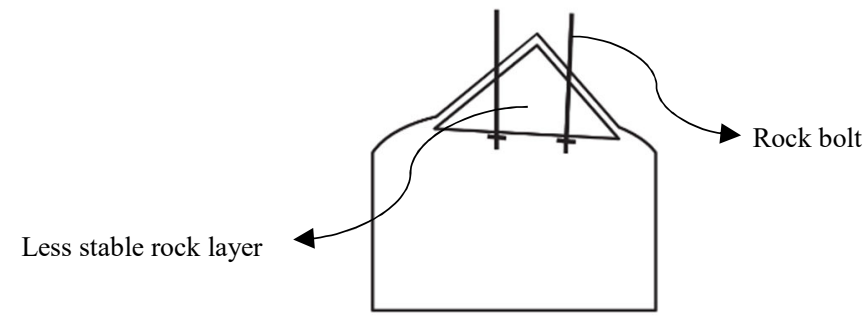

Figure 2 Illustration of rock bolt on the top (roof) of the underground structure (Li, 2017)

\section{Friction bolt/Split set}

Split Set application system as shown in Figure 3. is by inserting a steel tube and installing a plate on its head by pushing it into a drill hole which has smaller diameter than the split set diameter. When split set inserted into the drill hole by rotating it slowly, a radial force will be formed on the split set material, causing an anchor effect along the drill hole. The relatively easy process of installing split sets makes this support element widely used by underground structures practitioners. Implementing split sets together with mesh/screens will help keep loose rock from falling. Corrosion is a major problem for split sets since surface protection is still not considered sufficient for rust prevention. Galvanized coating on split sets can help reduce corrosion processes but is still not reliable for long term applications or at more aggressive environments.

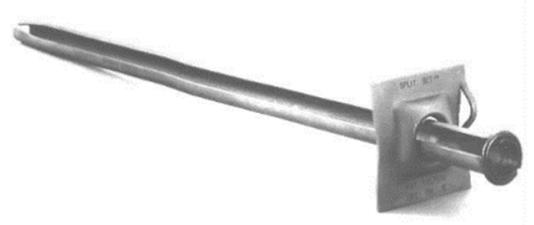

Figure 3 Friction bolt / Split set (Hoek, 1993) 


\section{$\underline{\text { Grout bolt }}$}

Grout bolt application uses grout as an adhesive material to distribute stresses in the rock. The grout used consists of two types, namely cement and chemical resin. When using cement grout bolt, quality control of cement grout is highly demanded, especially in terms of w/c ratio (water/cement ratio). The optimal value of $\mathrm{w} / \mathrm{c}$ ratio for cement grout bolt application is 0.4 . Resin grout bolts use materials such as polyester capsules and containers as reaction catalysts that are mixed by inserting and rotating the bolt simultaneously in the borehole.

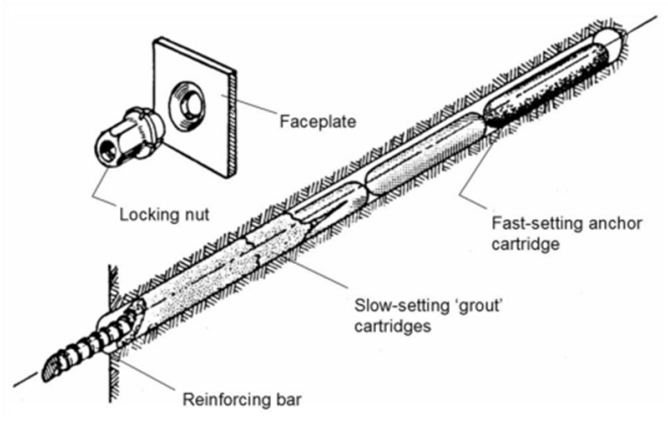

Figure 4 Illustration of resin grout bolt application (Hoek, 1993)

\section{Mechanical point anchor}

Mechanically point anchor is a rock bolt that is mechanically anchored by a material that is placed at the end that goes into the drill hole.

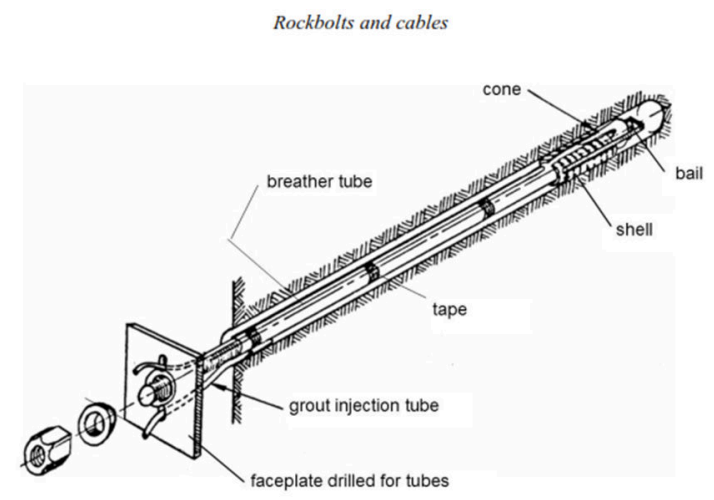

Figure 5 Mechanical Point Anchor (Hoek, 1993)

\subsection{Mesh/Screen}

The function of mesh or screen is to prevent small rock fragments from falling. This support element consists of two types, namely chain link mesh and weld mesh. Chain link mesh installation tends to be more difficult and less suitable when used as shotcrete reinforcement. This condition occurs because it will be easier for air pockets to form behind the mesh bond, thereby reducing the strengthening function of the shotcrete. Weld mesh is made by welding process at each joint point. The process of installing weld mesh tends to be easier and more 
suitable for use as shotcrete reinforcement because the shotcrete material is easier to enter into the weld mesh gap thereby reducing air pockets formation. However, chain link mesh offers a higher deflection capability than the weld mesh (Hadjigeorgiou \& Charette, 2001).
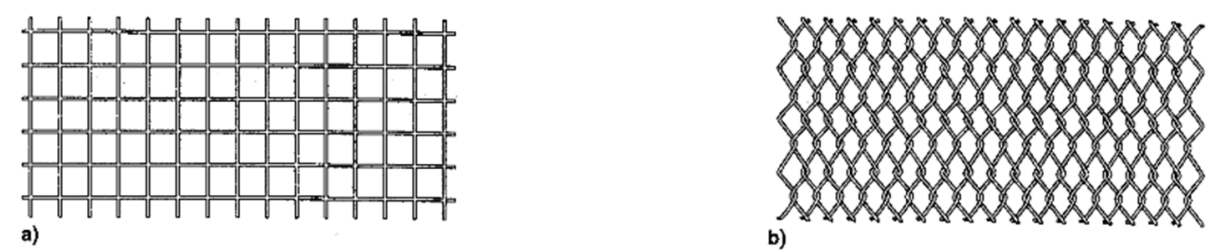

Figure 6 (a) Weld mesh (b) Chain link mesh (Hadjigeorgiou \& Charette, 2001)

\subsection{Straps}

Straps are used in areas with weak rock layers and as a reinforcement in pillar areas of underground structures. The application of straps will be more effective when installed in the intersection direction of weak rock layers.

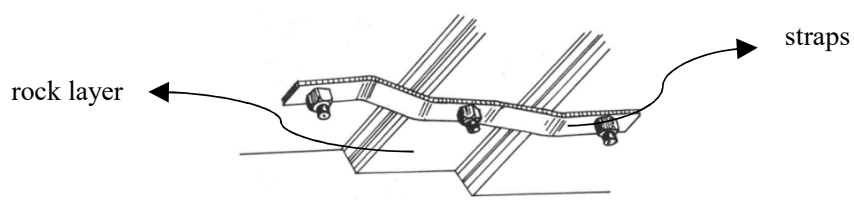

Figure 7 Illustration of straps installed on rock surface (Hoek \& Wood, 1987)

\subsection{Steel Sets}

Steel Set is one of the supporting elements of underground support system made of steel. The use of steel sets has replaced timber as a traditional support system. The use of steel sets is starting to be limited because its function as a support can be more effectively carried out by rock bolt together with shotcrete, except for the rock mass at fault area. Steel sets will be required in this case as rock bolt installation in weak rock layers will be difficult, especially those associated with fault areas.

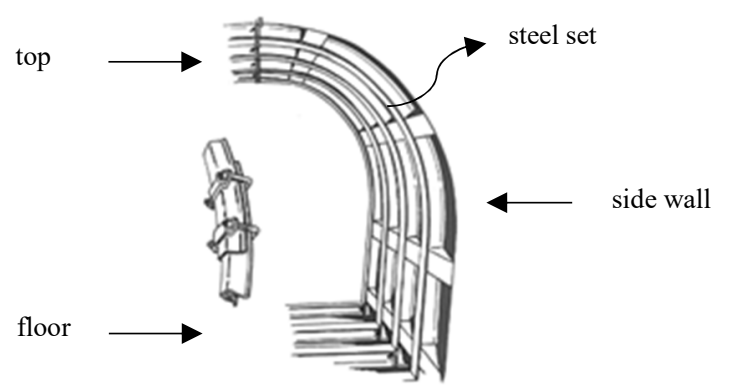

Figure 8 Illustration of steel set installed on rock surface (Hoek \& Wood. 1987) 


\subsection{Shotcrete lining}

Shotcrete is a general name for a mixture of cement, sand, coarse aggregate which is applied by a pneumatic process until it is compacted by high air pressure (Hoek, 1993). There are two ways in the implementation process, namely dry mix and wet mix. The difference lies in the mixing of water with cement, sand, and coarse aggregate. Water will be added at the nozzle in dry mix system, whereas in wet mix system, water is mixed with other materials at batch plant. The end products of the two systems are very similar so the selection is based more on workability and production capacity. Dry mix systems are often used in the mining sector, as they use smaller equipment making them easier to transport. Wet mix systems are typically used for high production shotcrete in long or large underground structures.

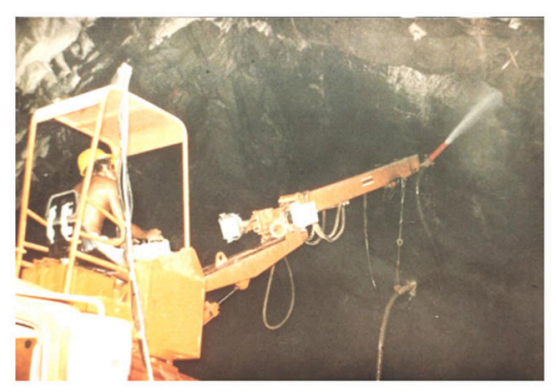

Figure 9 Shotcrete spraying process using 'roboshot' (Hoek, 1993)

The use of fibre in shotcrete to increase tensile strength was introduced in the 1970s and was accepted as an alternative to screen/mesh as reinforcement. The main purpose of reinforcement using fibre in shotcrete is to provide ductility so that brittleness can be reduced. Ductility in shotcrete is needed when the rock mass undergoes large non-elastic deformation due to the movement of the rock mass.

\subsection{Concrete lining}

Concrete lining can be a solution for underground structures that require smooth longitudinal profiles such as aqueduct tunnels and transportation tunnels (roads and trains). In addition, concrete lining can also help protect the support system from erosion and corrosion (Gharouni-Nik et al., 2013). Its application process to the underground support system is divided into two, namely in situ and precast concrete.

In situ

The process of making concrete layer is carried out exactly at the rock to be supported by making a mold first and then concrete is poured by pumping. In situ method is suitable for application in underground structures that have irregular geometries. In situ method allows the shape of the concrete to change as geometry change of the rock surface.

\section{Precast concrete}

The process of making concrete layer is not exactly carried out at rock mass to be supported, but it has been casted before and then installed using supporting equipment. Precast concrete is often used in support systems using Tunnel Boring Machine (TBM) technology, which is then known as the segmented concrete lining. The quality control of concrete in this method will be better maintained than in situ method due to the environment characteristic which tends to meet the requirements during the concrete molding process. 


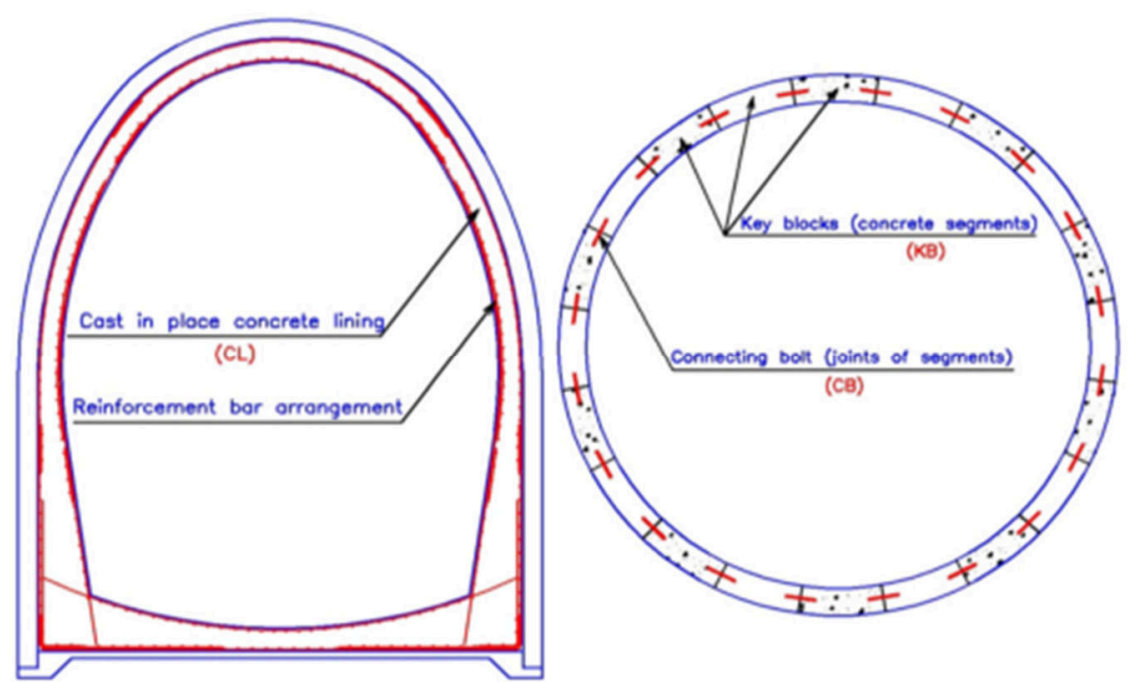

Figure 10 Cross section of tunnel with concrete lining In Situ method (left); Cross section of tunnel with concrete lining Precast method (right). (Gharouni-Nik et al, 2013)

\subsection{Grout Injection}

Grout injection technology for the stability of underground structures can be divided into two, namely preinjection, and post injection. These two injection methods are widely used in the world and have different approaches to the process. In principle, grout injection is used as rock mass reinforcement aiming to fill voids, rock mass consolidation and to seal uncontrol water that enters the underground space. Grout injection material can use cement grout or chemicals such as polyurethane and urea-silicate resin.

\section{Pre-Injection}

Pre-injection is a grout material injection system using high pressure into the rock mass at the face of drift tunnel. The aim is to treat unstable and impermeable rock masses to be relatively safe prior to excavation. The advantage of treating rock mass at drift face is that the water pressure and falling rock conditions can be more controlled so as to prevent excessive water seepage into the underground and modify the rock mass prior to excavation. This condition eventually prevents collapse and the potential flooding of the underground (Northcroft, 2006).

The first step in this process is to make a probe hole at drift face area. The purpose of the probe hole is to check the presence of water seepage that enters the ground and whether the rock mass condition is poor as an indication of unstable rock mass. The information obtained from the probe hole will be a parameter to assess the condition of whether pre-injection work is needed and to determine what material will be used as grout in the pre-injection process. The grout material commonly used for pre-injection is a kind of micro cement with a grain size of less than 20 microns. This is intended to make it easier for grout to penetrate small rock cavities. 


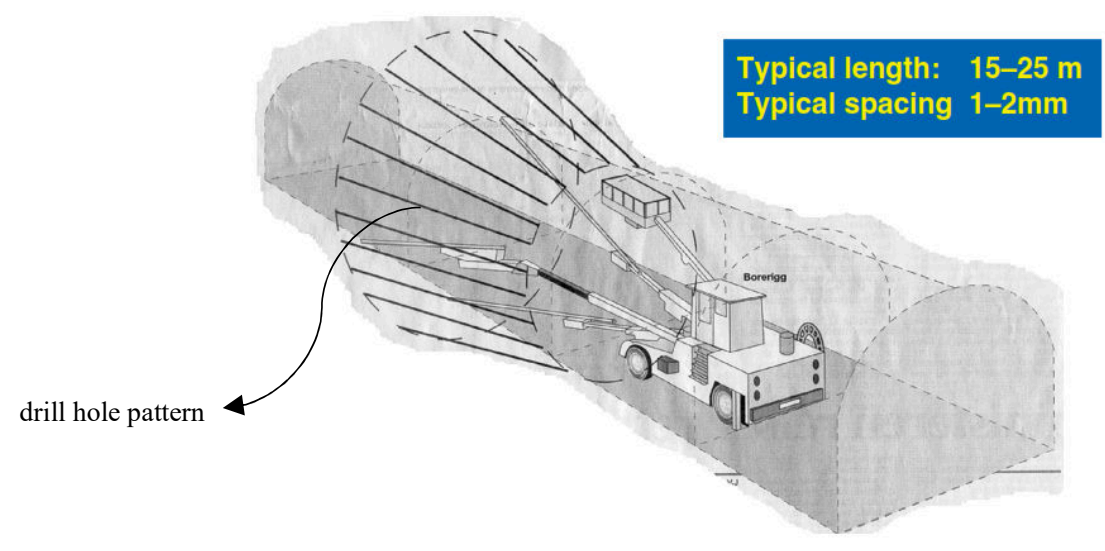

Figure 11 Drill hole pattern at drift face for pre-injection work (Northcroft, 2006)

\section{Post Injection}

Post-injection is a grout material injection system using high pressure into rock mass after the drift opened. The purpose is to treat unstable and impermeable rock masses to be relatively safe after excavation. This process usually uses a variety of resin chemicals such as polyurethane and urea-silicate which the selection depends on the purpose of injection. The purpose of post injection can be divided into to seal uncontrol water or to fill the cavity of the rock mass in order to create stability.

\section{Selection of Support Elements}

Underground support system is a combination of applications from several supporting elements. Several methods have been developed in selecting support elements to form integrated support system, namely through empirical approach and finite element method. Determination of support system through an empirical approach is closely related to the rock mass classification system. The final product of this classification system will recommend support elements for the system that will be used for the stability of underground structure. On the other hand, finite element method is a powerful tool for analyzing complex engineering problems due to the flexibility of input parameters.

\subsection{Empirical Approach}

The empirical approach relates to some real experiences that have been encountered in previous cases in anticipating conditions at each different ground. Bieniawsky (1989) argues that if the empirical approach is supported by a systematic approach to rock classification, this valuable practical experience will effectively be very helpful for engineering judgment. Rock mass classification, which forms the basis of empirical approaches, has often been used in the construction of underground structures, especially in tunnels. 'Terzaghi rock classification' is a classification that was first developed and was introduced in the 1940s.

At this time there are many rock mass classification systems, but the ones that are often used by practitioners of underground structures are the Rock Mass Rating (RMR) and Q-System. These two systems were developed from Rock Quality Designation (RQD) which was initiated by Deere (1964) as a quantitative method. RQD is simple so that the value is less detailed but is still widely used as one of the quantitative test parameters in rock mass classification. The RQD concept is to calculate the percentage the length of rock pieces $(>100 \mathrm{~mm})$ 
against length of bore hole. As shown in Table 1., the higher the RQD value, the better the rock quality. In general, RQD value is obtained from the following equation:

$$
R Q D(\%)=100 \times \frac{\text { rock pieces }(>100 \mathrm{~mm})}{\text { length of bore hole }}
$$

Table 1 Rock mass quality classification according to RQD (Deere et al., 1967)

\begin{tabular}{cc}
\hline RQD & Rock Mass Quality \\
\hline$<25$ & Very poor \\
\hline $25-50$ & Poor \\
\hline $50-75$ & Fair \\
\hline $75-90$ & Good \\
\hline $99-100$ & Excellent \\
\hline
\end{tabular}

Support system diagram based on RQD classification is shown in Figure 12. The RQD system has several weaknesses (Siswanto \& Anggraini, 2018):

- When drilling does not produce core samples (no recovery),

- Difficulty in obtaining data on alluvium rocks,

- Core sample results will be disturbed when there are layers of soft materials or voids, and

- RQD results which are only based on the length of rock pieces do not represent the strength of rock.

The limitations of RQD classification system become the reason for geotechnical experts to make improvements by adding several parameters. However, RQD remains one of the inputs in the developed classification method.

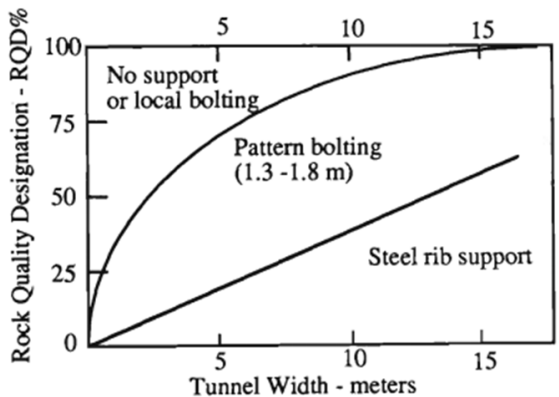

Figure 12 Support system recommendation by RQD classification (Merritt, 1972)

Bieniawsky $(1973,1976,1989)$ developed RMR classification system that uses six parameters to determine its value, namely Uniaxial Compressive Strength (UCS), Rock Quality Designation (RQD), spacing of discontinuities, condition of discontinuities, groundwater condition, and orientation of discontinuities. Each parameter describes the quality of the rock being tested. The sum of the values for each parameter will be the total RMR value shown by the following equation:

$$
R M R=R M R_{\text {basic }}+\text { adjustment } R M R_{\text {basic }}=\sum \text { parameter }(\mathrm{i}+\mathrm{ii}+\mathrm{iii}+\mathrm{iv}+\mathrm{v})
$$


The value in final result is grouped into 5 rock mass classes, each class has a value range of 20 points. RMR classification ratings and support system recommendations can be seen in the table below.

Table 2 Support system recommendations by RMR classification (Bieniawski, 1989)

\begin{tabular}{|c|c|c|c|c|}
\hline Rock mass class & Excavation & $\begin{array}{c}\text { Rock bolts ( } 20 \mathrm{~mm} \\
\text { diameter, fully grouted) }\end{array}$ & Shotcrete & Steel sets \\
\hline $\begin{array}{l}\text { I - Very good rock } \\
\text { RMR: } 81-100\end{array}$ & Full face, $3 \mathrm{~m}$ advance & \multicolumn{3}{|c|}{ no support required except spot bolting (generally) } \\
\hline $\begin{array}{l}\text { II - Good rock } \\
\text { RMR: } 61-80\end{array}$ & $\begin{array}{l}\text { Full face, } 1-1.5 \mathrm{~m} \\
\text { advance. } \quad \text { Complete } \\
\text { support } 20 \mathrm{~m} \text { from face. }\end{array}$ & $\begin{array}{l}\text { Locally, bolts in crown } \\
3 \mathrm{~m} \text { long, spaced } 2.5 \mathrm{~m} \\
\text { with occasional wire } \\
\text { mesh. }\end{array}$ & $\begin{array}{l}50 \mathrm{~mm} \text { in crown where } \\
\text { required. }\end{array}$ & None \\
\hline $\begin{array}{l}\text { III - Fair rock } \\
\text { RMR: } 41-60\end{array}$ & $\begin{array}{l}\text { Top heading and bench } \\
1.5-3 \mathrm{~m} \text { advance in top } \\
\text { heading. Commence } \\
\text { support after each blast. } \\
\text { Complete support } 10 \mathrm{~m} \\
\text { from face. }\end{array}$ & $\begin{array}{l}\text { Systematic bolts } 4 \mathrm{~m} \\
\text { long, spaced } 1.5-2 \mathrm{~m} \text { in } \\
\text { crown and walls with } \\
\text { wire mesh in crown. }\end{array}$ & $\begin{array}{l}50-100 \mathrm{~mm} \text { in crown } \\
\text { and } 30 \mathrm{~mm} \text { in sides. }\end{array}$ & None \\
\hline $\begin{array}{l}\text { IV - Poor rock } \\
\text { RMR: } 21-40\end{array}$ & $\begin{array}{l}\text { Top heading and bench } \\
1.0-1.5 \mathrm{~m} \text { advance in } \\
\text { top heading. Install } \\
\text { support concurrently } \\
\text { with excavation, } 10 \mathrm{~m} \\
\text { from face. }\end{array}$ & $\begin{array}{l}\text { Systematic bolts } 4-5 \mathrm{~m} \\
\text { long, spaced } 1-1.5 \mathrm{~m} \text { in } \\
\text { crown and walls with } \\
\text { wire mesh. }\end{array}$ & $\begin{array}{l}100-150 \mathrm{~mm} \text { in crown } \\
\text { and } 100 \mathrm{~mm} \text { in sides. }\end{array}$ & $\begin{array}{l}\text { Light to medium ribs } \\
\text { spaced } 1.5 \mathrm{~m} \text { where } \\
\text { required. }\end{array}$ \\
\hline $\begin{array}{l}\text { V-Very poor rock } \\
\text { RMR: }<20\end{array}$ & $\begin{array}{l}\text { Multiple drifts } 0.5-1.5 \\
\mathrm{~m} \text { advance in top } \\
\text { heading. Install support } \\
\text { concurrently with } \\
\text { excavation. Shotcrete as } \\
\text { soon as possible after } \\
\text { blasting. }\end{array}$ & $\begin{array}{l}\text { Systematic bolts } 5-6 \mathrm{~m} \\
\text { long, spaced } 1-1.5 \mathrm{~m} \text { in } \\
\text { crown and walls with } \\
\text { wire mesh. Bolt invert. }\end{array}$ & $\begin{array}{l}150-200 \mathrm{~mm} \text { in crown } \\
\text { and } 150 \mathrm{~mm} \text { in sides, } \\
\text { and } 50 \mathrm{~mm} \text { on face }\end{array}$ & $\begin{array}{l}\text { Medium to heavy ribs } \\
\text { spaced } 0.75 \mathrm{~m} \text { with steel } \\
\text { lagging and fore poling } \\
\text { if required. Closed } \\
\text { invert. }\end{array}$ \\
\hline
\end{tabular}

Barton et al. (1974) developed another concept of rock classification system known as the Q-System. It is a system that takes into account six parameters, namely RQD, joint set number $\left(\mathrm{J}_{\mathrm{n}}\right)$, joint roughness $\left(\mathrm{J}_{\mathrm{r}}\right)$, joint alteration $\left(J_{a}\right)$, joint water reduction factor $\left(J_{w}\right)$, and Stress Reduction Factor (SRF). The Q-System formula can be seen below.

$$
Q=\left[\frac{R Q D}{J_{n}}\right] \cdot\left[\frac{J_{r}}{J_{a}}\right] \cdot\left[\frac{J_{w}}{S R F}\right]
$$

From the above equation, Q-System can be considered as a function of:
- Block size
$\left(\mathrm{RQD} / \mathrm{J}_{\mathrm{n}}\right)$
- Roughness characteristic
$\left(\mathrm{J}_{\mathrm{r}} / \mathrm{J}_{\mathrm{n}}\right)$
- Active stress
$\left(\mathrm{J}_{\mathrm{w}} / \mathrm{SRF}\right)$ 
Q-system recommendations can be seen in the diagram below.

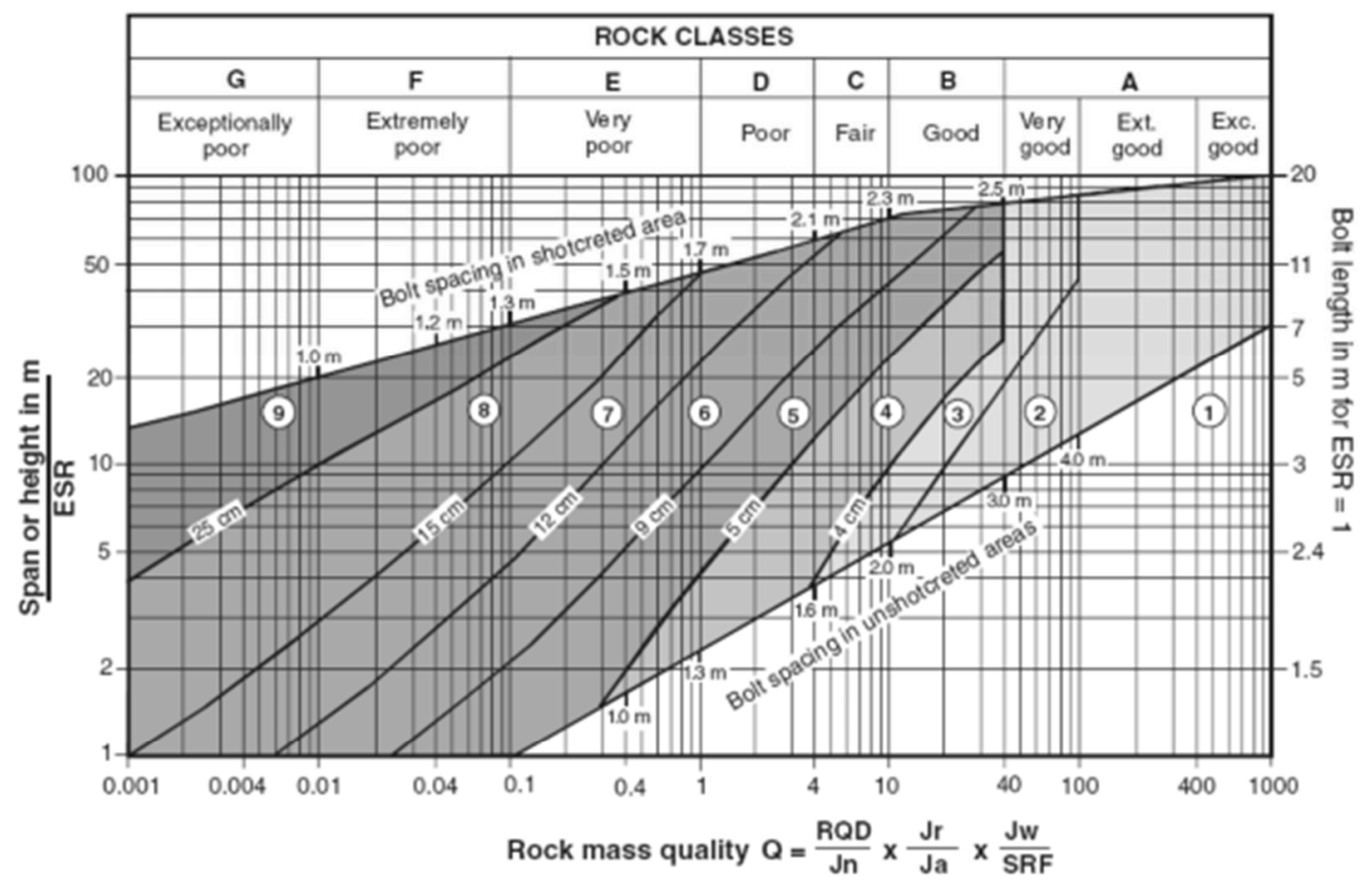

REINFORCEMENT CATEGORIES:

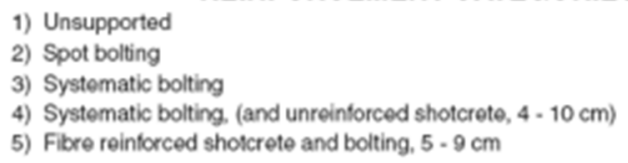
6) Fibre reinforced shotcrete and bolting. $9-12 \mathrm{~cm}$
7) Fibre reinforced shotcrete and bolting, $12-15 \mathrm{~cm}$
8) Fibre reinforced shotcrete, $>15 \mathrm{~cm}$,
reinforced ribs of shotcrete and bolting
9) Cast concrete lining

Figure 13 Support system recommendations by Q-System classification (Barton et al., 1974)

\subsection{Finite element method}

Finite element method is a sophisticated form of numerical analysis that studies in how a complex structure behaves using computational calculations. Its principle is to solve complex or difficult problems by dividing them into small parts so that they become simpler to solve. The basic concept of the finite element method is 'discretion' which assumes that the deformation distribution is difficult to find in conventional ways so that computational calculations are needed to solve the problem (Schutz, 2010). Calculation using finite element method aims to determine stresses and deformations in underground structures. The output of calculation is a probable node displacement in element resulting from a change in stress due to drift opening. The selection of required support elements depends on the results of these calculations. The finite element method is a practical approach with acceptable deviation tolerances.

The following explanation, taken from Brady \& Brown (2005), is not intended to provide a complete explanation of the finite element method. The explanation is intended to show the basic principles of finite element method. Figure 14a. illustrates a cross-sectional section of an underground opening made in an infinitely continuous medium subjected to initial stresses $p_{x x}, p_{y y}$, and $p_{x y}$. In Figure 14b., the selected boundary 
of the problem domain is indicated, and appropriate support and conditions are determined at the outer boundary so that the problem can be solved statically. The domain is divided into a series of triangular elements. An element that represents the series is illustrated in Figure 14c., where the points $i, j$, and $k$ are the nodes of the element. The problem is to determine the conditions for the total stress and displacement induced by excavation through a finite element method. The strain components are uniquely defined from several displacement derivatives. The imposed displacement variation determines the strain conditions in an element. These induced strains and the elastic properties of the medium together determine the induced stress in an element. Superposition of the initial stresses and the induced stresses will give the total stress in the element.

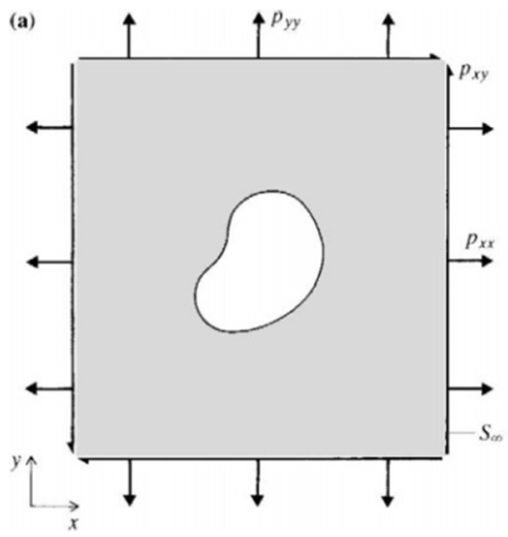

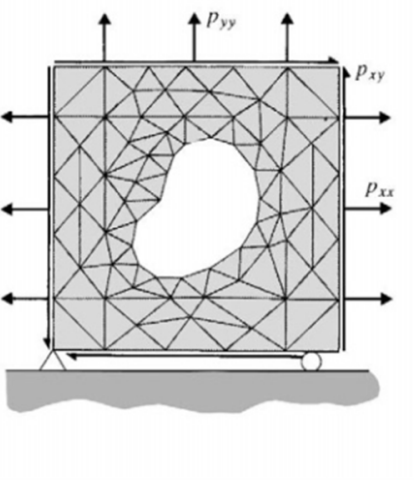

(c)

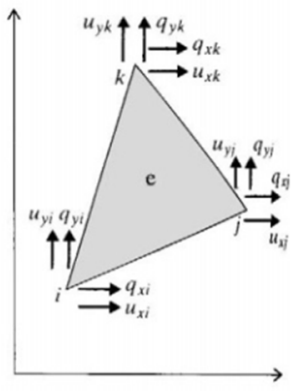

Figure 14 Development of a finite element model of a continuum problem (Brady \& Brown, 2005)

\section{Discussion}

\subsection{Supporting element classification}

From the previous description, a classification diagram of the supporting elements (Figure 15) is made based on their active or passive characteristic (Hoek \& Wood, 1987) and based on the function of reinforcement, hold, and retain (Kaiser et al., 1996). The support system has active characteristic if the supporting elements provide support from within the rock mass and has passive characteristic if the supporting elements provide support from outside the rock mass. The active characteristic serves as reinforcement and anchoring (to hold), while passive characteristic is to retain. Based on classification, the supporting elements that have active properties namely grout injection, grout bolt, friction bolt and mechanical point anchor, while mesh, straps, steel set, shotcrete lining and concrete lining are belong to passive characteristic. Both the two characteristics (active and passive) and the three support system functions (reinforcement, hold, and retain) have different usability philosophies. These differences in characteristics and functions when used together will become an integrated system in rock support. Currently, various types and technologies of underground support elements have been introduced by many manufactures. The classification of support elements based on their characteristics and functions is intended to help practitioners and academics to determine the appropriate supporting elements according to the behavior of the rock mass being handled. 


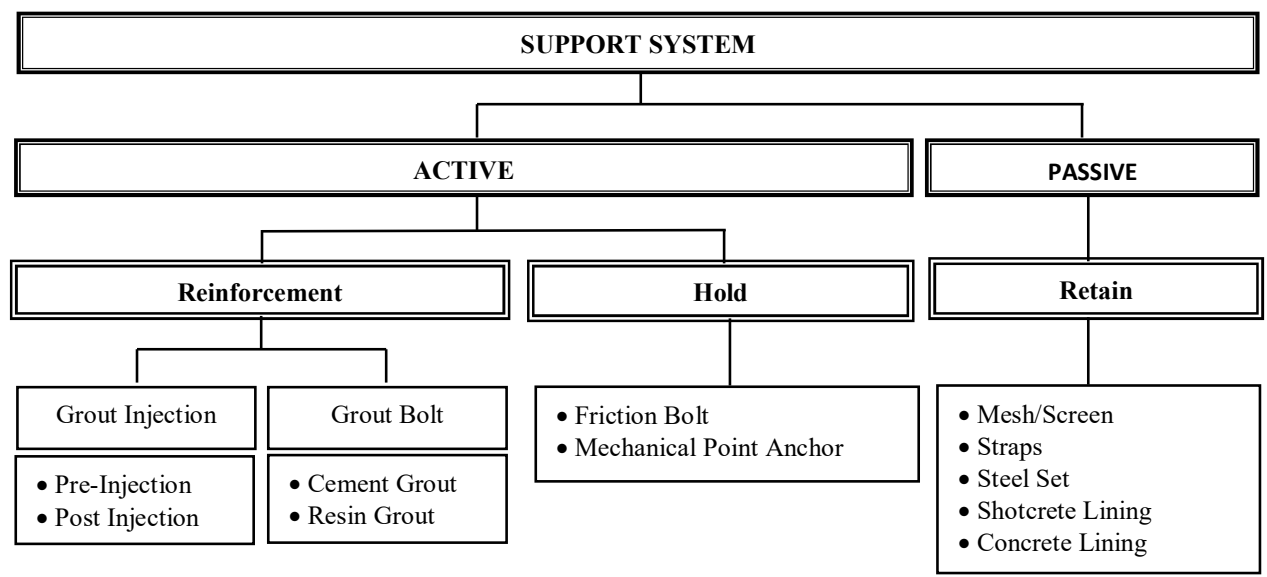

Figure 15 Support element classification diagram

\subsection{Selection of support system determination method}

Determination of support system with empirical approach offered by Q-system and RMR does not cover the reinforcement aspect that can be done by grout injection. The method also does not clearly state the specifications for steel set and concrete lining as a retain function. Both Q-System and RMR only recommend rock bolt, mesh, shotcrete, steel set and concrete lining as hold and retain functions. However, at the initial planning stage, the empirical method approach is considered quite optimal as an initial recommendation to rock support system due to its practicality. On the other hand, the finite element method offers a more complex variety of input parameters to determine stresses and deformations in specific area. This method allows all the characteristics and functions of the supporting elements to be applied. Since the output of the calculation results (stress and deformation) are specific, the support element specifications can be more clearly defined. However, some boundary condition parameters still have to be assumed in an attempt to simplify the problem so that it can be solved. Therefore, engineering judgment from practical experience is needed to produce output that is close to reality in the field.

The safety is always be the main aspect for the stability of subsurface structure. Investigation of support system determination must be carried out thoroughly, either through an empirical approach or finite element method (analytical) approach. This is the same as what Bieniawsky (1989) stated that rock mass classification is not intended to replace analytical methods, observation and engineering judgment. Therefore, rock mass classification must be used in conjunction with analytical methods to produce a safe design according to the geological conditions of the project site.

\section{Conclusion}

A support system consists of several support elements, each of which has one of the functions of reinforcement, hold, or retain. 'Reinforcement' and 'hold' function have active characteristics while 'retain' has passive characteristics. Active characteristic is used to increase strength in preventing the deformation behavior of the rock mass while passive characteristic is used to prevent loose rock from separating. Grout injection and grout bolt are support elements that function as reinforcement. Friction bolt and mechanical point 
anchor serve to hold whilst mesh, straps, steel set, shotcrete and concrete lining serve to retain loose rock from falling. In addition to understanding the classification of support elements, an understanding of various methods of determining support systems is also required. Both Q-System and RMR as empirical method only recommend rock bolt, mesh, shotcrete, steel set and concrete lining as support system. The empirical method does not cover grout injection which has reinforcement function. However, empirical approach is considered quite optimal as an initial recommendation to rock support system due to its practicality. The finite element method allows all the characteristics and functions of the supporting elements to be applied. Since the output of the calculation results (stress and deformation) are specific, the support element specifications can be more clearly defined. However, some boundary condition parameters still have to be assumed in an attempt to simplify the problem so that it can be solved. Each method has its own strengths and weaknesses in determining the support system and therefore must be used together to produce a safe design according to the geological conditions of the project site.

\section{References}

Barton, N., Lien, R., \& Lunde, J. 1974. Engineering Classification of Rock Masses for The Design of Tunnel Support. Rock Mechanics, Volume 6 (1974): 189-236.

Bieniawski, Z.T. 1973. Engineering Classification of Jointed Rock Masses. The Civil Engineer in South Africa, 15 (1973): $335-344$

Bieniawsky, Z.T. 1976. Rock Mass Classification in Rock Engineering. Proceedings of Exploration for Rock Engineering, 1: 97-106. Balkema. Cape Town.

Bieniawsky, Z.T. 1989. Tunnel Design By Rock Mass Classification. Pennsylvania State University (Department of Mineral Engineering). Pennsylvania.

Brady, B. H. G. \& Brown, E. T. 2005. Rock Mechanics for Underground Mining, $3^{\text {rd }}$ Edition. USA: Springer Science + Business Media, Inc.

Chen, D. 1994. Design of Rockbolting System of Underground Excavation. University of Wollongong (Thesis Collection). Australia.

Deere, D.U. 1964. Technical description of rock cores for engineering purposes. Rock Mechanics and Engineering Geology (1964), 1(1): 16-22.

Deere, D.U., Hendron, A.J., Patton, F.D., \& Cording, E.J. 1967. Design of surface and near surface construction in rock. In: Proceedings of the 8th U.S. Symposium on Rock Mechanicse Failure and Breakage of Rock. New York: American Institute of Mining, Metallurgical and Petroleum Engineers, Inc.; 1967. p. 237-302.

Gharouni-Nik, M., Naeimi, M., Ahadi, S., \& Alimoradi, Z. 2013. Reliability Analysis of Idealized Tunnel Support System Using Probability-Based Methodes With Case Studies. International Journal of Advance Engineering, 6:53 (2014).

Hadjigeorgiou, J. \& Charette, F. 2001. Rockbolting for Underground Excavations. Underground Mining Methodes: Engineering Fundamentals and International Case Studies (Chapter 63). Society for Mining, Metallurgy and Exploration Inc. Englewood, Chicago.

Hoek, E. 1993. Practical of Rock Engineering. University of Toronto. Canada.

Hoek, E. \& Wood, D. F. 1987. Support in Underground Hard Rock Mines. Underground Support System. Montreal; Canadian Institute of Mining and Metallurgy. Special Volume 35 (1987) pages 1-6.

Kaiser, P. K., Tannant, D. D., \& McCreath, D. R. 1996. Canadian rockburst support handbook. Sudbury, Ontario: Geomechanics Research Centre, Laurentian University.

Li, C. C. 2017. Principles of Rockbolting Design. Journal of Rock Mechanics and Geotechnical Engineering, Volume 9 (2017): $396-414$.

Li, Z., Wang, L., Feng, B., Xiao, J., Zhang, Q., Li, L., \& Liang, J. 2020. Comprehensive collapse investigation and treatment: An engineering case from Qingdao expressway tunnel. Journal of cleaner production. 121879 .

Merritt, A.H. 1972. Geologic prediction for underground excavations. Proceedings of North American Rapid Excavation and Tunneling Conference. Chicago. K.S. Lane and L.A. Garfield, 1 (1972): 115-132.

Northcroft, I. W. 2006. Innovative materials and methods for ground support, consolidation and water sealing for the mining industry. The Journal of The Southern African Institute of Mining and Metallurgy, Volume 106 (2006): 835-844.

Priest, S. D. 1993. Discontinuity Analysis for Rock Engineering. Springer Science + Business Media. Berlin.

Schutz, R. 2010. Numerical modelling of Shotcrete for Tunnelling. Imperial College London (Thesis). London.

Siswanto \& Anggraini, D. 2018. Perbandingan Klasifikasi Massa Batuan Kuantitatif: Q, RMR, dan RMi. Jurnal Geosains dan Teknologi, Volume 1. No.2, Universitas Diponegoro. 